\section{Bavaria begins mandatory AIDS tests in the face of criticism}

\section{Munich}

Compulsory AIDS tests for prostitutes, intravenous drug users and other suspected AIDS (acquired immune deficiency syndrome) carriers will be introduced in the West German Land of Bavaria on 1 June, following a unanimous vote in the Bavarian cabinet. The decision to declare AIDS an epidemic and to take extreme measures to "protect the healthy" has set Bavaria at odds with other Länder and provoked strong criticism from the federal government.

The final form of the Bavarian AIDS programme, which has been under discussion since February, retains measures for the "isolation" of AIDS carriers who behave in an "unreasonable" way, such as prostitutes who do not use condoms. But the programme no longer demands that all immigrants from countries outside the European Economic Community be tested for AIDS. Immigrants from other Western European countries such as Austria, Switzerland and Scandinavia will now be exempt from the tests.

Furthermore, people seen "associating with" members of high-risk groups are no longer included in the mandatory testing category. Nor will people accused anonymously be considered for testing. But applicants for public service jobs will still be tested and rejected if found positive for human immunodeficiency virus (HIV).

The measures dealing with the behaviour of prostitutes have been ridiculed along with their author Peter Gauweiler (Christian Social Union), state secretary in the Bavarian Interior Ministry. Prostitutes found not to be AIDS carriers are required to report for quarterly AIDS antibody tests and to use condoms. But when asked how he planned to enforce the latter measure, Gauweiler could only reply that he would depend on "(female) informers from that milieu".

West German officials criticized the Bavarian measures and announced their intention to continue to support publicity and counselling to combat AIDS. West German Health Minister Rita Süssmuth (Christian Democrat) said the Bavarian programme would give the population a "false sense of security". West Berlin Senator Ulf Fink said that the measures would hasten the spread of the disease. There have been about 1,000 cases of AIDS reported in West Germany, and an estimated 50,000 to 100,000 carriers.

In particular, the measures calling for "isolation" of recalcitrant AIDS carriers have met with hostility from a wide range of politicians. Alfons Metzger, speaker for the Bavarian Interior Ministry, defended the measure as a step to "protect the healthy, not the sick". The hospitals and institutions where violators are to be held have not yet been selected, he said, but that decision will not have to be made "tomorrow morning". The decision to "isolate" someone will proceed through the courts, he explained, "just like the commitment of a dangerous person to a mental institution".

The testing of public service applicants was categorically rejected by the public service union, the Deutschen Beamten

\section{London}

WESTERN psychiatrists should be wary of Soviet attempts to gain readmission to the World Psychiatric Association, Dr Anatolii Koryagin warned last week. Koryagin, who served a seven-year prison sentence for informing his colleagues abroad (in an

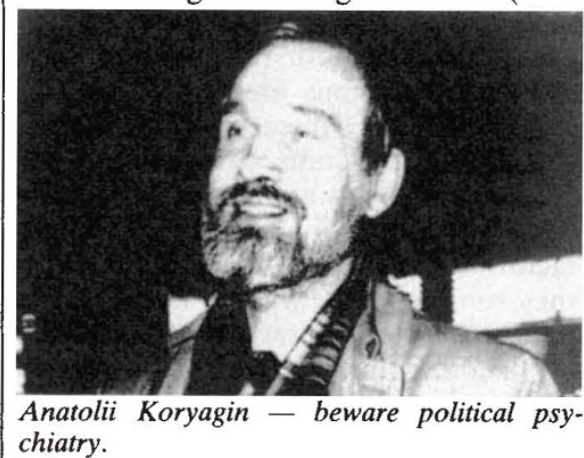
chiatry.

article in The Lancet) of the practice of 'political psychiatry' in the Soviet Union, and who was allowed to emigrate to the West a few weeks ago, has been visiting the United States, where he addressed the American Psychiatric Association and also the American Enterprise Institute. Recent reports in the Soviet press of malpractices in Soviet mental hospitals, he warned, are simply an attempt to use the current policy of glasnost to detract from the real problem.

The media reports, Koryagin stressed, deal essentially with the practices of corruption, negligence and laisse $z$-faire endemic in the Soviet system. The current Gorbachev line encourages criticism of such phenomena in the name of greater efficiency, and so the media are able to criticize psychiatrists who accept bribes from criminals to provide diagnoses which will result in a mitigation of sentence. But the far more serious problem of the use of psychiatric hospitals and neuroleptic drugs as a means of punishing political activists and dissidents remains unchanged.
Bund (DBB). DBB speaker Dieter Fengels said that this measure might serve as a signal to private industry and might lead to "stigmatization" of AIDS carriers throughout German society. Metzger defended the measure, comparing it to similar rules forbidding the hiring of diabetics or hypertensives for government service.

Encouraged by the Bavarian cabinet's decision, Gauweiler and his allies in the Christian Social Union, including West German Interior Minister Friedrich Zimmermann, are expected to push for national acceptance of a similar plan. Their chances of winning approval are thought slim.

Steven Dickman

\title{
Warning from Soviet psychiatrist on doubtful practices
}

Western concern about Soviet misuse of psychiatry for political ends led, in 1983, to the tabling of a number of motions of censure to be raised at the Vienna Congress of the World Psychiatric Association (WPA). Before these motions could be formally raised, the Soviet delegation (together with several delegations from the socialist bloc) resigned from the WPA. The Soviet resignation was accepted with "regret", and a motion from the UK Royal College of Psychiatrists by an overwhelming majority assured the Soviets that they would be welcome to rejoin as soon as they can prove they have abandoned doubtful practices. During the past two years, there have been several discreet hints from the Soviet psychiatric establishment that it would like to reapply for admission to the WPA before its next congress, due in Athens in 1987. but, says Koryagin, before the Soviets are readmitted, they should comply, and be seen to comply, with three conditions.

First, he said, the Soviet Union should admit that it has been making improper use of psychiatric methods and drugs to punish its political opponents. This would entail not merely verbal admissions, but also the establishment of some kind of tribunal to attribute responsibility to those concerned in the abuses, and the rapudiation of the current Soviet theory that dissent is a symptom of mental disorder.

Second, said Koryagin, all "psychiatric prisoners of conscience" should be released, and, finally, the Soviet All-Union Society of Neuropathologists and Psychiatrists (the professional association for Soviet psychiatrists) should agree to participate in the international commission established by the WPA to investigate reports of psychiatric abuse worldwide - a commission which at present has little more than a paper existence, largely due to the current attitude of the Soviet Union.
Vera Rich 